Int. J. Dev. Biol. 51: 655-661 (2007)

doi: $10.1387 / \mathrm{ijdb} .072372 \mathrm{rm}$

\title{
Stem cells for the replacement of inner ear neurons and hair cells
}

\author{
RODRIGO MARTINEZ-MONEDERO ${ }^{1,2}$ and ALBERT S.B. EDGE*,1,2,3 \\ ${ }^{1}$ Department of Otology and Laryngology, Harvard Medical School, Boston, MA ${ }^{2}$ Tillotson Unit for Cell Biology, Eaton-Peabody Labora- \\ tory, Massachusetts Eye and Ear Infirmary, Boston, MA and ${ }^{3}$ Program in Speech and Hearing Bioscience and Technology, Division of \\ Health Science and Technology, Harvard \& MIT, Cambridge, MA, USA
}

\begin{abstract}
Stem cells in the nervous system have some capacity to restore damaged tissue. Proliferation of stem cells endows them with self-renewal ability and accounts for in vitro formation of neurospheres, clonally derived colonies of floating cells. However, damage to the nervous system is not readily repaired, suggesting that the stem cells do not provide an easily recruited source of cells for regeneration. The vestibular and auditory organs, despite their limited ability to replace damaged cells, appear to contain cells with stem cell properties. These inner ear stem cells, identified by neurosphere formation and by their expression of markers of inner ear progenitors, can differentiate to hair cells and neurons. Differentiated cells obtained from inner ear stem cells expressed sensory neuron markers and, after co-culture with the organ of Corti, grew processes that extended to hair cells. The neurons expressed synaptic vesicle markers at points of contact with hair cells. Exogenous stem cells have also been used for hair cell and neuron replacement. Embryonic stem cells are one potential source of both hair cells and sensory neurons. Neural progenitors made from embryonic stem cells, transplanted into the inner ear of gerbils that had been de-afferented by treatment with a toxin, differentiated into cells that expressed neuronal markers and grew processes both peripherally into the organ of Corti and centrally. The regrowth of these neurons suggests that it may be possible to replace auditory neurons that have degenerated with neurons that restore auditory function by regenerating connections to hair cells.
\end{abstract}

KEY WORDS: cell therapy, hearing, guidance, regeneration

Endogenous stem cells provide regenerative capacity to adult tissues by their ability to continually self-renew and differentiate and these properties allow them to replace cells lost through normal turnover or after tissue damage. A number of studies have demonstrated the occurrence of stem cells in the central nervous system (Doetsch et al., 1999, Gage, 2000, Kondo and Raff, 2000, Lie et al., 2004, Pevny and Rao, 2003, Rietze et al., 2001, Temple, 2001), and, although there is little constitutive turnover, stem cells can be recruited to replace lost neurons (Bauer et al., 2003, Kempermann et al., 2004, Ohori et al., 2006). Neural stem cells are present in the subventricular zone of the lateral ventricles and in the dentate gyrus (Taupin and Gage, 2002, Watts et al., 2005) and have also been demonstrated in the peripheral nervous system (Dromard et al., 2007, Hjerling-Leffler et al., 2005). Progenitors for peripheral neurons arise from the neural crest (Crane and Trainor, 2006, Greenwood et al., 1999, Tomita et al., 2005) and derivatives of the neural crest that can give rise to autonomic and sensory neurons persist in adult tissues. The existence of stem cells in the peripheral and central nervous systems has been demonstrated by in vivo studies using genetic tracers to reveal the origin of differentiated cells and by in vitro criteria, such as the expression of markers of stem cells and the capacity to form neurospheres (Reynolds and Weiss, 1992). However, the capacity for regeneration by stem cells in the nervous system is limited, and, therefore, little recovery is seen after damage in the CNS. Even at sites where stem cells that undergo cell division in vitro have been identified, regeneration is modest (Kempermann et al., 2004, Taupin and Gage, 2002).

Our aim in this review is to cover the evidence for hair cell and neuronal regeneration in the inner ear both from endogenous stem cells and by transplantation of exogenous stem cells. These are covered in two sections. In the section on endogenous stem cells, we confine our discussion to the generation

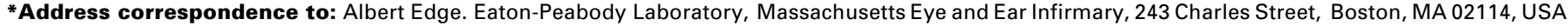
Fax: +1-617-720-4408. e-mail: albert_edge@meei.harvard.edu
} 
of cells from progenitors and do not include regeneration by division of preexisting hair cells (Sage et al., 2005) or by differentiation of other mature, defined cochlear cells to hair cells (Izumikawa et al., 2005, White et al., 2006). It is possible that these two routes to generation of hair cells - from stem cell progenitors and from other cell types - will turn out to be very similar processes when more has been learned about the identity of the progenitor cells. In the second section on cell transplantation, we look at recent evidence for cell replacement in the cochlea.

Repair of lesioned peripheral nerves can also be accomplished by the regeneration of motor and sensory neuronal processes (Brushart, 1993, Mi et al., 2007). Interactions with extracellular factors from glial cells as well the targets of the growing axon have been shown to have an influence on the regrowth of these processes and formation of new synapses (Fraher, 2000, Harel and Strittmatter, 2006, Hata et al., 2006, Pasterkamp and Verhaagen, 2006).

\section{Formation of inner ear cells from endogenous stem cells}

The formation of spheres from individual cells dissociated from the utricular epithelium was used to demonstrate that stem cells were present in the inner ear ( $\mathrm{Li}$ et al., 2003a). The spheres were clonal (Li et al., 2003a) and differentiated into cell

A

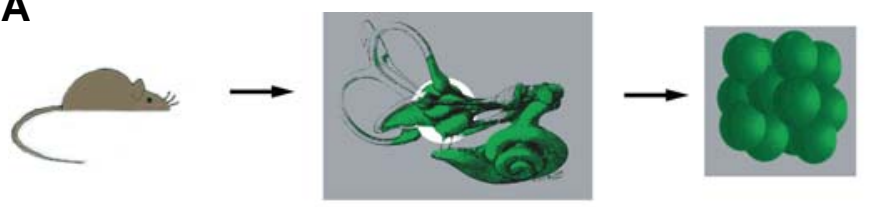

types corresponding to all three germ layers, endoderm, mesoderm and ectoderm ( $\mathrm{Li}$ et al., 2003a), indicating that the stem cells were pluripotent (Fig. 1). We generated spheres from cochlear sensory epithelia and spiral ganglia of mice (Oshima et al., 2007). The stem cells in spheres proliferated, as required for self-renewal and they had the capacity to differentiate into neurons and hair cells (Martinez-Monedero etal., 2007, Oshima et al., 2007). The demonstration that inner ear progenitor cells could differentiate into hair cells and neurons in vitro raised the possibility that they could be induced to differentiate in vivo as the basis for future therapies to replace cells in the inner ear.

The sphere-forming capacity of both cochlear and vestibular organs diminished after the early postnatal period (Oshima et al., 2007), consistent with the idea that the number of stem cells decreased after birth or that they lost their capacity to proliferate. In the vestibular organs, cells that retained the capacity to divide and differentiate into more specialized cells persisted longer than in the cochlea.

A postnatal loss of stem cells has been observed in adult eyes with a similar time frame as the inner ear. Retinal stem cells that give rise to retinal ganglion cells are found postnatally but diminish in number during early postnatal life in the rodent (Reh and Fischer, 2006). In contrast, others have demonstrated the presence of neural progenitor cells in the adult human auditory nerve, with the expression of nestin-positive neural progenitors that divided and expressed markers found in inner ear sensory neurons like TrkB and TrkC (Rask-Andersen et al., 2005). It is possible that some stem cells are left as an animal matures, but that they proliferate less rapidly in the adult.

Despite the pluripotent differentiation potential of these cells, however, recovery doesn't occur to any significant extent after damage to hair cells or neurons in the mammalian cochlea. This is in contrast to adult vestibular organs where some cells with the capacity to divide and differentiate into hair cells are retained (Forge et al., 1993, Warchol et al., 1993). Regeneration of cochlear neurons is not observed after degeneration (Carnicero et al., 2002, Sekiya et al., 2003) and damage to neurons therefore leads to permanent deafness. Even if the cell bodies and central axons survive, loss of hearing can still result from degeneration of peripheral processes (Nadol, 1997). Primary cochlear neuronal degeneration has been described in a variety of pathologies (Starr et al., 1996, Varga et al., 2003) and can occur due to insults to the cochlea, such as exposure to sound pressure levels that do not cause hair cell loss (Kujawa and Liberman, 2006).

Secondary degeneration commonly follows sen-
D

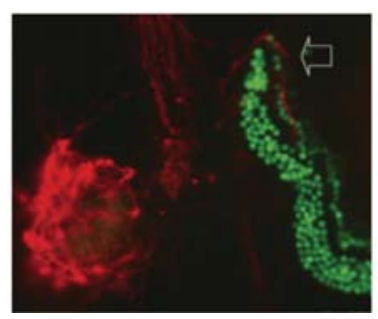

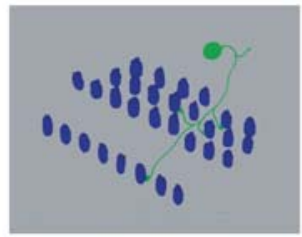

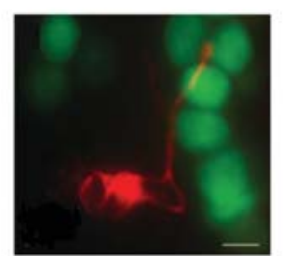

Fig. 1. Neurons differentiated from inner ear stem cells. (A) Stem cells isolated by sphere formation from the vestibular organs of a mouse. Clonal spheres are observed after 7-14 days in nonadherent culture. (B) Spheres derived from the inner ear differentiate into nestin and $\beta$-III tubulin-positive neurons upon culture as attached progenitor cells in a dish. (C) Schematic of an inner ear sphere in culture with an organ of Corti showing growth of neural processes to contact hair cells. (D) Spiral ganglion neurons (stained for $\beta$-III tubulin) placed in culture with an explant of the organ of Corti that had been denervated with $\beta$-bungarotoxin (green hair cells from a Math1-nGFP mouse). The neurons isolated from a newborn mouse grow processes that appear to be attracted by and form contacts with hair cells. 
sory epithelial degeneration and neuronal cell death occurs due to a lack of trophic support (Fritzsch et al., 1997). Disruption of function studies in mice have shown that survival of spiral ganglion neurons is dependent on a number of genes such as the neurotrophins (Ernfors et al., 1995, Hossain et al., 2002), components of the erbB pathway (Stankovic et al., 2004) and cAMP-dependent protein kinase (Bok et al., 2003). Protection of auditory neurons by a variety of interventions has been demonstrated and neurotrophins have been shown to augment neuronal survival in the ear (Miller et al., 1997, Wise et al., 2005).

Although the neurons do not regenerate once they are lost, spiral ganglion neurons have been shown to regrow fibers to varying extents after damage in different animal models. Several studies suggested that the endings reconnected to hair cells (Puel et al., 1997, Sekiya et al., 2003) and that these new connections were functional (Puel et al., 1997). Experimental sectioning of the auditory nerve in mice led to extensive regrowth of fibers into the cochlea (Sugawara et al., 2005). However, in humans, the extent of regrowth does not appear to be clinically significant (Nadol, 1997). Regrowth of these processes may be increased by NT-3 and BDNF, which were reported to increase peripheral connections in guinea pigs, even when administered 33 days after kanamycin treatment to damage neurons and hair cells (Wise et al., 2005).

The existence of endogenous stem cells in the mammalian cochlea opens the door to new approaches to repair of a damaged cochlea by cell proliferation and differentiation. A potential new approach could be envisaged if the pluripotency of these progenitor cells could be harnessed. Stem cells or cells with stem cell-like properties might be directed toward a hair cell phenotype or a neuronal phenotype to replace degenerated neurons and hair cells and restore function to the inner ear.

Characterization of the differentiation capacity of inner ear stem cells revealed that proliferating cells that were positive for BrdU staining expressed neural stem cell markers, Musashi and nestin and embryonic stem cell markers (Ivanova et al., 2006), Sox2, Tbx3 and Tc/1 (Martinez-Monedero et al., 2007). These cells could be obtained from cochlear and vestibular organs and gave rise to hair cells, based on marker identification and on electrophysiology that demonstrated the currentvoltage relationships of an E16 utricular hair cell (Oshima et al., 2007). The presence of inner ear cells that could give rise to hair cells has been demonstrated from neonatal mouse and rat cochlea (Doetzlhofer et al., 2004, Malgrange et al., 2002, White et al., 2006, Yerukhimovich et al., 2007, Zhai et al., 2005) and supporting cells can act as progenitors of hair cells in vitro during this early postnatal period (Doetzlhofer et al., 2004, Malgrange et al., 2002, White et al., 2006). Inner ear hair cells produced from a cochlear cell line showed a response to mechanical vibrations (Liu et al., 2006).

These progenitors had the capacity to give rise to a broad array of neuronal types. Thus, the stem cells could be converted to dopamine neurons, cholinergic neurons and seritonergic neurons (Martinez-Monedero et al., 2007). However, the largest number of inner ear stem cell-derived neurons were glutamatergic and had glutamate receptors. These neurons expressed markers of sensory neurons, both immature (Brn3a, Ngn1 and NeuroD) and mature (TrkB, TrkC and peripherin) and markers of developing auditory neurons like GATA3. They also expressed genes associated with the embryonic inner ear like Pax2 and islet1. Differentiation of these cells as functional neurons was further confirmed by electrophysiological activity (Martinez-Monedero et al., 2007).

Immortalized cochlear cell lines have also been shown to differentiate to cells with many of the characteristics of auditory neurons (Nicholl et al., 2005). These cells may recapitulate the early developmental steps in spiral ganglion formation and can be expanded indefinitely, making them potentially useful for cell transplantation experiments in the inner ear.

The neurons derived by differentiation of inner ear stem cells grew processes that contacted hair cells in an explant of the organ of Corti that had been denervated by $\beta$-bungarotoxin (Martinez-Monedero et al., 2007). This was similar to what had been observed previously in this in vitro model system using newborn spiral ganglion neurons (Martinez-Monedero et al., 2006) (Fig. 1). Neurons had not been previously shown to regenerate synapses with hair cells, but we found that neurons from spiral ganglia of newborn mice contacted hair cells and expressed synapsin and SV2 at the sites of contact. The formation of new afferent connections is the key step in regeneration of a sensory organ and these new contacts suggested that primary afferent neurons might reform these connections. The new neurons appeared to have some properties of presynaptic neurons during synaptogenesis: the expression of synaptic markers was localized to the neuronal side at the actual contact with the hair cell (Martinez-Monedero et al., 2006). The processes of spiral ganglion neurons that extend to hair cells during development stain for synapsin and synaptophysin (Scarfone et al., 1991) and it is possible that the identity of this peripheral process as a dendrite is only acquired after it forms a connection to the hair cell. Neurite outgrowth has been shown to occur before the identity of axons and dendrites is specified. A single process can then take on an axonal identity and express axonal markers (Jiang et al., 2005, Schwamborn and Puschel, 2004). After making the first contact, hair cell signaling may provide the key to further development of the neuron. The influence of the synaptic contact on further differentiation of the neuron as well as the electrophysiology of the synapses formed by these new processes remain to be studied.

The formation of connections requires that neurons be able to find their targets. The pathfinding ability of the neurons may depend on the recognition of guidance signals by growing axons so that the neural process can respond to cues from hair cells, or these cues could be from glial and other nonneuronal cells that prevent growth to incorrect targets by expression of repulsive guidance cues (Dickson, 2002). Since targeted growth is observed in this system, the importance of a guidance molecule can be determined by the effect of gain or loss-offunction of the candidate gene.

Neuronal replacement will become increasingly important if attempts to regenerate hair cells are successful. Extensions from spiral ganglion neurons have been reported to re-form connections with hair cells that were generated from supporting cells after overexpression of Math1 using an adenovirus (Kawamoto et al., 2003), suggesting that neural processes may be attracted by the new cells. Excitation of hair cells that had been generated from an otocyst-derived cell line in vitrocaused 
a response in cocultured neurons, indicating regrowth of functional connections to hair cells (Liu et al., 2006).

\section{Regeneration of auditory neurons and hair cells from exogenous stem cells}

Attempts to make both auditory neurons and hair cells from mouse ES cells have been reported. Hair cells were obtained from mouse ES cells by addition of EGF, bFGF and IGF-1 (Li et al., 2003b). These cells expressed markers of developing and mature hair cells, Math1, Brn3c and myosin VIla and had stereociliary bundles that labeled for espin and F-actin. Sensory neurons or neurons with characteristics of auditory neurons have also been produced from ES cells (Coleman et al., 2007, Corrales et al., 2006). Human ES cells could be converted to progenitors that had the same markers as embryonic precursors of sensory neurons in the neural crest and sensory placodes, and these cells could be differentiated to neurons that had many of the characteristic markers of sensory neurons (Shi et al., 2007).

Hair cells have also been generated by application of growth factors to mesenchymal stem cells from bone marrow, followed by co-culture with the otocyst from chick (Jeon et al., 2007). Expression of Math 1 in the progenitor cells obtained from mesenchymal stem cells resulted in their conversion to hair cells (Jeon et al., 2007). In addition, recent reports have used other adult stem cells as a source of hair cells. Expression of hair cell markers was reported after co-culture of olfactory progenitors with supernatants from cochlear cultures (Doyle et al., 2007).
Bone marrow stem cells have been used to generate neurons with many of the characteristics of auditory afferent neurons (Kondo et al., 2005). The neurons expressed transcription factors of sensory neurons, GATA3 and Sox10, as well as AMPA receptors after treatment with retinoic acid and sonic hedgehog. The sensory neuron marker, Brn3a, was detected only after the neurons were cultured with a conditioned medium from E10 hindbrain/somite/otocyst, and these neurons extended processes in the direction of hair cells.

Exogenous stem cells have been used in attempts to replace degenerated auditory nerve. We found that progenitor cells derived from exogenous stem cells were effective in replacing the spiral ganglion neurons in an animal model of primary neuronal degeneration (Fig. 2) and that these neurons grew fibers into the organ of Corti where they appeared to contact hair cells (Corrales et al., 2006). The cell bodies of the engrafted neurons were within the track normally occupied by spiral ganglion axons and extended their processes both centrally and peripherally. The peripheral fibers grew in an apical direction in the nerve trunk and in fasciculating bundles of neurites that left the cochlear axis in a radial direction to Rosenthal's canal and through the osseous spiral lamina into the organ of Corti. The fibers thus grew peripherally from an ectopic location (the cochlear nerve trunk) to the site of the original cell bodies and from there to the hair cells and central fibers grew into the brainstem (Shi et al., 2007). Whether these neurons could restore function was not established.

Neurites from dorsal root ganglion cells transplanted into rats did not grow toward sensory cells (Hu et al., 2005a) and no

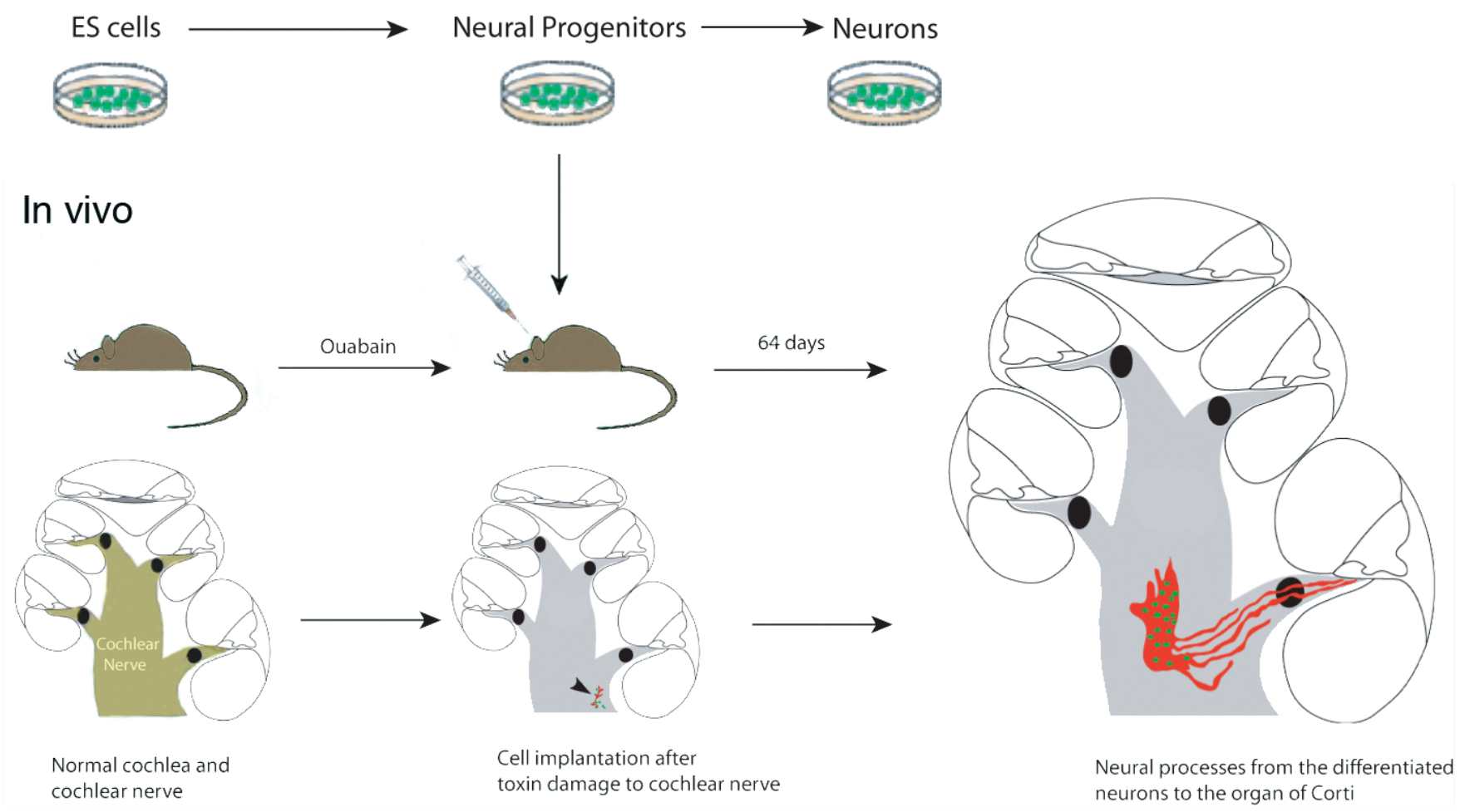

Fig. 2. Transplantation of neural progenitors derived from ES cells into the cochlea. When stem cell derived neural progenitors are injected into an ear that has had its auditory nerve removed by a toxin, the cells form a graft at the base of the cochlea and differentiate into neurons. The engrafted cells can be identified by endogenous EYFP and processes extending from these cells can be followed both apically within the modiolus of the cochlea and radially to the organ of Corti. They can be labeled for neuronal markers by immunofluorescence. The black circles indicate the location of Rosenthal's canal where the cell bodies of the afferent neurons are located in the normal animal. 
evidence was presented of neurite outgrowth toward hair cells from neural stem cells transplanted into the inner ear of guinea pigs (Hu et al., 2005b). However, the neurons of the host animal were not removed and the cells were placed in the scala tympani, which makes it difficult to assess whether central and peripheral processes of the spiral ganglia could be regenerated. Neural stem cells have been used for transplantation into the cochlea of a mouse that had been treated with cisplatin to remove endogenous neurons and the cells were present in the cochlea two weeks after grafting (Tamura et al., 2004). ES cell-derived neural progenitors made contacts with vestibular hair cells (Kim et al., 2005) and ES cell transplantation into guinea pig cochlea resulted in growth of processes, although the processes did not appear to grow toward the organ of Corti (Okano et al., 2005). ES cells transplanted into the cochlear modiolus of animals with damaged spiral ganglion neurons grew fibers along the remaining neurons and to the organ of Corti (Sekiya et al., 2006).

The task of replacing hair cells with transplanted cells has been difficult to achieve. There has been little information on integration or function of stem cells transplanted into sensory epithelia, despite some reports of cells recovered in the organ of Corti, but there have been advances in ways to obtain hair cells from stem cells that should lead to progress by improving their availability (Jeon et al., 2007, Minoda et al., 2004, Tateya et al., 2003).

\section{Possible approaches to future regeneration of neurons and hair cells}

How can the regrowth of neurons to their targets in the cochlea and brainstem be improved? One key to regrowth may lie in overcoming inhibition imposed by factors in the extracellular space of the cochlea. In neuronal regeneration in the eye, olfactory system and spinal cord, inhibitors of axonal growth have been shown to prevent regenerating neurons from extending processes to their targets (Fraher, 2000, Pasterkamp and Verhaagen, 2006, Shirvan et al., 2002). Blocking the inhibitory molecules has been partially successful in achieving regrowth of these axons. For example, an inhibitor of semaphorin $3 a$ that overcame its repulsive effect increased axonal growth in injured spinal cord (Kaneko et al., 2006), a semaphorin 3a antibody increased optic nerve regeneration (Shirvan etal., 2002) and siRNAs that blocked signaling by semaphorin 3a prevented axonal growth cone collapse (Hengst et al., 2006). An antibody to Nogo or a dominantnegative form of the Nogo receptor also had an effect on the regeneration of spinal cord neurons (Liebscher et al., 2005) and visual system neurons (Fischer et al., 2004). An antibody to RGMa led to corticospinal neuron regeneration in injured spinal cord (Hata et al., 2006).

Many factors that block regrowth have a guidance function during development that prevents incorrect routing of embryonic axons. In the olfactory system, semaphorin 3 a has this function and its expression in glial scars prevents axon regeneration (Pasterkamp et al., 1998, Pasterkamp and Verhaagen, 2006, Schwarting et al., 2004). Determination of which guidance molecules are expressed in the adult mouse inner ear would make it possible to test the effect on axonal regeneration of overcoming this inhibition.

Because endogenous stem cells of the cochlea and vestibular system can be differentiated into sensory neurons and these neurons can make new connections to hair cells, it is possible to envisage these endogenous stem cells as precursors in vivo for spiral ganglion neuron replacement. The synapses formed must be further characterized by recording the activity of hair cells and neurons at newly formed synapses. If the cells can be induced to differentiate into sensory neurons as they have been in vitro, they could repair damaged tissue. It might be possible to manipulate these cells with drugs or gene therapy so that they become responsive to signals from degenerating cells and enter the cell cycle.

Activation of endogenous stem cells could prove to be the most promising avenue for replacement of hair cells. Several recent studies show that gene silencing or overexpression can result in hair cell formation in vivo. Manipulations of developmental pathways that lead to extra hair cell formation in mouse models (Chen and Segil, 1999; Izumikawa et al., 2005; Sage et al., 2005) suggest options for hair cell differentiation that can be studied using inner ear stem cells. Genetic manipulation and drug therapy are both possible routes to activation of selected cells leading to hair cell regeneration.

Cell transplantation appears to hold great promise but there are critical issues that must be addressed: the choice of cell type, the timing of infusion relative to the damage and the stage of differentiation of the transplanted cells at the time of infusion. The stage at which hair cell progenitors are transplanted could have a major effect on their ability to interact with the proper cells in the sensory epithelium so that they can regenerate the correct cellcell contacts. For neuronal regrowth, placement of cells to avoid scar and allow the neurons to grow to peripheral and central targets can be a problem, particularly for cells that are placed peripherally and need to grow centrally through the Schwann-glial border (Fraher, 2000, Pasterkamp et al., 1998). The neural regeneration results suggest that neurons may be able to remake connections to hair cells, and it may, therefore, be possible to restore function if neuronal regeneration is combined with therapies to replace hair cells.

\section{Acknowledgements}

Supported by grants RO1 DC007174 and P30 DC05209 from the National Institute on Deafness and other Communicative Disorders (NIDCD). RMM was sponsored by the Programa nacionalpara la movilidad de profesores de Universidad e investigadores, Secretaria de Estado de Educacion y Universidades, Spain and by the National Organization of Hearing Research (NOHR).

\section{References}

BAUER, S., RASIKA, S., HAN, J., MAUDUIT, C., RACCURT, M., MOREL, G., JOURDAN, F., BENAHMED, M., MOYSE, E. and PATTERSON, P.H. (2003). Leukemia inhibitory factor is a key signal for injury-induced neurogenesis in the adult mouse olfactory epithelium. J Neurosci 23: 1792-803.

BOK, J., ZHA, X.M., CHO, Y.S. and GREEN, S.H. (2003). An extranuclear locus of cAMP-dependent protein kinase action is necessary and sufficient for promotion of spiral ganglion neuronal survival by cAMP. J Neurosci23: 777-87.

BRUSHART, T.M. (1993). Motor axons preferentially reinnervate motor pathways. $J$ Neurosci13: 2730-8.

CARNICERO, E., KNIPPER, M., TAN, J., ALONSO, M.T. and SCHIMMANG, T. (2002). Herpes simplex virus type 1-mediated transfer of neurotrophin-3 stimulates survival of chicken auditory sensory neurons. Neurosci Lett321: 149-52.

CHEN, P. and SEGIL, N. (1999). p27Kip1 links cell proliferation to morphogenesis in the developing organ of Corti. Development 126: 1581-1590. 
COLEMAN, B., FALLON, J.B., PETTINGILL, L.N., DE SILVA, M.G. and SHEPHERD, R.K. (2007). Auditory hair cell explant co-cultures promote the differentiation of stem cells into bipolar neurons. Exp Cell Res 313: 232-43.

CORRALES, C.E., PAN, L., LI, H., LIBERMAN, M.C., HELLER, S. and EDGE, A.S. (2006). Engraftment and differentiation of embryonic stem cell-derived neural progenitor cells in the cochlear nerve trunk: Growth of processes into the organ of corti. J Neurobio/66: 1489-500.

CRANE, J.F. and TRAINOR, P.A. (2006). Neural crest stem and progenitor cells. Annu Rev Cell Dev Biol22: 267-86.

DICKSON, B.J. (2002). Molecular mechanisms of axon guidance. Science 298: 1959-64.

DOETSCH, F., CAILLE, I., LIM, D.A., GARCIA-VERDUGO, J.M. and ALVAREZBUYLLA, A. (1999). Subventricular zone astrocytes are neural stem cells in the adult mammalian brain. Cel/97: 703-16.

DOETZLHOFER, A., WHITE, P.M., JOHNSON, J.E., SEGIL, N. and GROVES, A.K. (2004). In vitro growth and differentiation of mammalian sensory hair cell progenitors: a requirement for EGF and periotic mesenchyme. Dev Bio/272: 432-47.

DOYLE, K.L., KAZDA, A., HORT, Y., MCKAY, S.M. and OLESKEVICH, S. (2007). Differentiation of adult mouse olfactory precursor cells into hair cells in vitro. Stem Cells 25: 621-7.

DROMARD, C., BARTOLAMI, S., DELEYROLLE, L., TAKEBAYASHI, H., RIPOLL, C., SIMONNEAU, L., PROME, S., PUECH, S., TRAN, V.B., DUPERRAY, C. et al. (2007). NG2 and Olig2 expression provides evidence for phenotypic deregulation of cultured central nervous system and peripheral nervous system neural precursor cells. Stem Cells 25: 340-53.

ERNFORS, P., VAN DE WATER, T., LORING, J. and JAENISCH, R. (1995). Complementary roles of BDNF and NT-3 in vestibular and auditory development. Neuron 14: 1153-64.

FISCHER, D., HE, Z. and BENOWITZ, L.I. (2004). Counteracting the Nogo receptor enhances optic nerve regeneration if retinal ganglion cells are in an active growth state. JNeurosci24: 1646-51.

FORGE, A., LI, L., CORWIN, J.T. and NEVILL, G. (1993). Ultrastructural evidence for hair cell regeneration in the mammalian inner ear. Science 259: 1616-9.

FRAHER, J.P. (2000). The transitional zone and CNS regeneration. J Anat 196 (Pt 1): $137-58$.

FRITZSCH, B., FARINAS, I. and REICHARDT, L.F. (1997). Lack of neurotrophin 3 causes losses of both classes of spiral ganglion neurons in the cochlea in a region-specific fashion. JNeurosci17: 6213-25.

GAGE, F.H. (2000). Mammalian neural stem cells. Science 287: 1433-8.

GREENWOOD, A.L., TURNER, E.E. and ANDERSON, D.J. (1999). Identification of dividing, determined sensory neuron precursors in the mammalian neural crest. Development 126: 3545-59.

HAREL, N.Y. and STRITTMATTER, S.M. (2006). Can regenerating axons recapitulate developmental guidance during recovery from spinal cord injury? Nat Rev Neurosci 7: 603-16.

HATA, K., FUJITANI, M., YASUDA, Y., DOYA, H., SAITO, T., YAMAGISHI, S., MUELLER, B.K. and YAMASHITA, T. (2006). RGMa inhibition promotes axonal growth and recovery after spinal cord injury. J Cel/ Bio/173: 47-58.

HENGST, U., COX, L.J., MACOSKO, E.Z. and JAFFREY, S.R. (2006). Functional and selective RNA interference in developing axons and growth cones. $J$ Neurosci26: 5727-32.

HJERLiNG-LEFFleR, J., MARMigeRE, F., HEGliND, M., CEDERBERG, A., KOLTZENBURG, M., ENERBACK, S. and ERNFORS, P. (2005). The boundary cap: a source of neural crest stem cells that generate multiple sensory neuron subtypes. Development 132: 2623-32.

HOSSAIN, W.A., BRUMWELL, C.L. and MOREST, D.K. (2002). Sequential interactions of fibroblast growth factor-2, brain-derived neurotrophic factor, neurotrophin-3 and their receptors define critical periods in the development of cochlear ganglion cells. Exp Neuro/175: 138-51.

HU, Z., ULFENDAHL, M. and OLIVIUS, N.P. (2005a). NGF stimulates extensive neurite outgrowth from implanted dorsal root ganglion neurons following transplantation into the adult rat inner ear. Neurobiol Dis 18: 184-92.

HU, Z., WEI, D., JOHANSSON, C.B., HOLMSTROM, N., DUAN, M., FRISEN, J. and ULFENDAHL, M. (2005b). Survival and neural differentiation of adult neural stem cells transplanted into the mature inner ear. Exp Cell Res 302: 40-7.

IVANOVA, N., DOBRIN, R., LU, R., KOTENKO, I., LEVORSE, J., DECOSTE, C., SCHAFER, X., LUN, Y. and LEMISCHKA, I.R. (2006). Dissecting self-renewal in stem cells with RNA interference. Nature 442: 533-8.

IZUMIKAWA, M., MINODA, R., KAWAMOTO, K., ABRASHKIN, K.A., SWIDERSKI, D.L., DOLAN, D.F., BROUGH, D.E. and RAPHAEL, Y. (2005). Auditory hair cell replacement and hearing improvement by Atoh1 gene therapy in deaf mammals. Nat Med 11: 271-6.

JEON, S.J., OSHIMA, K., HELLER, S. and EDGE, A.S. (2007). Bone marrow mesenchymal stem cells are progenitors in vitro for inner ear hair cells. $\mathrm{Mol} \mathrm{Cell}$ Neurosci34: 59-68.

JIANG, H., GUO, W., LIANG, X. and RAO, Y. (2005). Both the establishment and the maintenance of neuronal polarity require active mechanisms: critical roles of GSK-3beta and its upstream regulators. Cel/120: 123-35.

KANEKO, S., IWANAMI, A., NAKAMURA, M., KISHINO, A., KIKUCHI, K., SHIBATA, S., OKANO, H.J., IKEGAMI, T., MORIYA, A., KONISHI, O. et al. (2006). A selective Sema3A inhibitor enhances regenerative responses and functional recovery of the injured spinal cord. Nat Med 12: 1380-9.

KAWAMOTO, K., ISHIMOTO, S., MINODA, R., BROUGH, D.E. and RAPHAEL, Y. (2003). Math1 gene transfer generates new cochlear hair cells in mature guinea pigs in vivo. JNeurosci23: 4395-400.

KEMPERMANN, G., WISKOTT, L. and GAGE, F.H. (2004). Functional significance of adult neurogenesis. Curr Opin Neurobio/14: 186-91.

KIM, T.S., NAKAGAWA, T., KITA, T., HIGASHI, T., TAKEBAYASHI, S., MATSUMOTO, M., KOJIMA, K., SAKAMOTO, T. and ITO, J. (2005). Neural connections between embryonic stem cell-derived neurons and vestibular hair cells in vitro. Brain Res 1057: 127-33.

KONDO, T., JOHNSON, S.A., YODER, M.C., ROMAND, R. and HASHINO, E. (2005). Sonic hedgehog and retinoic acid synergistically promote sensory fate specification from bone marrow-derived pluripotent stem cells. Proc Nat/ Acad Sci USA 102: 4789-94.

KONDO, T. and RAFF, M. (2000). Oligodendrocyte precursor cells reprogrammed to become multipotential CNS stem cells. Science 289: 1754-7.

KUJAWA, S.G. and LIBERMAN, M.C. (2006). Acceleration of age-related hearing loss by early noise exposure: evidence of a misspent youth. J Neurosci 26: 2115-23.

LI, H., LIU, H. and HELLER, S. (2003a). Pluripotent stem cells from the adult mouse inner ear. Nat Med9: 1293-9.

LI, H., ROBLIN, G., LIU, H. and HELLER, S. (2003b). Generation of hair cells by stepwise differentiation of embryonic stem cells. Proc Natl Acad Sci USA 100: 13495-500.

LIE, D.C., SONG, H., COLAMARINO, S.A., MING, G.L. and GAGE, F.H. (2004). Neurogenesis in the adult brain: new strategies for central nervous system diseases. Annu Rev Pharmacol Toxico/44: 399-421.

LIEBSCHER, T., SCHNELL, L., SCHNELL, D., SCHOLL, J., SCHNEIDER, R., GULLO, M., FOUAD, K., MIR, A., RAUSCH, M., KINDLER, D. et al. (2005). Nogo-A antibody improves regeneration and locomotion of spinal cord-injured rats. Ann Neuro/58: 706-19.

LIU, J.J., SHIN, J.H., HYRC, K.L., LIU, S., LEI, D., HOLLEY, M.C. and BAO, J. (2006). Stem cell therapy for hearing loss: Math1 overexpression in VOT-E36 cells. Otol Neuroto/27: 414-21.

MALGRANGE, B., THIRY, M., VAN DE WATER, T.R., NGUYEN, L., MOONEN, G. and LEFEBVRE, P.P. (2002). Epithelial supporting cells can differentiate into outer hair cells and Deiters' cells in the cultured organ of Corti. Cell Mol Life Sci 59: 1744-57.

MARTINEZ-MONEDERO, R., CORRALES, C.E., CUAJUNGCO, M.P., HELLER, S. and EDGE, A.S. (2006). Reinnervation of hair cells by auditory neurons after selective removal of spiral ganglion neurons. J Neurobio/66: 319-31.

MARTINEZ-MONEDERO, R., YI, E., GLOWATZKI, E. and EDGE, A.S.B. (2007). Neurons derived from inner ear stem cells form synapses with de-afferented hair cells. Association for Research in Otolarygology Annual Meeting.

MI, R., CHEN, W. and HOKE, A. (2007). From the Cover: Pleiotrophin is a neurotrophic factor for spinal motor neurons. ProcNat/Acad SciUSA 104: 46649.

MILLER, J.M., CHI, D.H., O'KEEFFE, L.J., KRUSZKA, P., RAPHAEL, Y. and 
ALTSCHULER, R.A. (1997). Neurotrophins can enhance spiral ganglion cell survival after inner hair cell loss. Int J Dev Neurosci 15: 631-43.

MINODA, R., IZUMIKAWA, M., KAWAMOTO, K. and RAPHAEL, Y. (2004). Strategies for replacing lost cochlear hair cells. Neuroreport 15: 1089-92.

NADOL, J.B., JR. (1997). Patterns of neural degeneration in the human cochlea and auditory nerve: implications for cochlear implantation. Otolaryngol Head Neck Surg 117: 220-8.

NICHOLL, A.J., KNEEBONE, A., DAVIES, D., CACCIABUE-RIVOLTA, D.I., RIVOLTA, M.N., COFFEY, P. and HOLLEY, M.C. (2005). Differentiation of an auditory neuronal cell line suitable for cell transplantation. Eur J Neurosci22: 343-53.

OHORI, Y., YAMAMOTO, S., NAGAO, M., SUGIMORI, M., YAMAMOTO, N., NAKAMURA, K. and NAKAFUKU, M. (2006). Growth factor treatment and genetic manipulation stimulate neurogenesis and oligodendrogenesis by endogenous neural progenitors in the injured adult spinal cord. J Neurosci 26: 11948-60.

OKANO, T., NAKAGAWA, T., ENDO, T., KIM, T.S., KITA, T., TAMURA, T., MATSUMOTO, M., OHNO, T., SAKAMOTO, T., IGUCHI, F. et al. (2005). Engraftment of embryonic stem cell-derived neurons into the cochlear modiolus. Neuroreport 16: 1919-22.

OSHIMA, K., GRIMM, C.M., CORRALES, C.E., SENN, P., MARTINEZMONEDERO, R., GELEOC, G.S., EDGE, A., HOLT, J.R. and HELLER, S. (2007). Differential distribution of stem cells in the auditory and vestibular organs of the inner ear. $J$ Assoc Res Otolaryngo/8: 18-31.

PASTERKAMP, R.J., DE WINTER, F., HOLTMAAT, A.J. and VERHAAGEN, J. (1998). Evidence for a role of the chemorepellent semaphorin III and its receptor neuropilin-1 in the regeneration of primary olfactory axons. JNeurosci18: 996276.

PASTERKAMP, R.J. and VERHAAGEN, J. (2006). Semaphorins in axon regeneration: developmental guidance molecules gone wrong? Philos Trans $R$ Soc Lond B Biol Sci361: 1499-511.

PEVNY, L. and RAO, M.S. (2003). The stem-cell menagerie. Trends Neurosci26: 351-9.

PUEL, J.L., D'ALDIN, C., RUEL, J., LADRECH, S. and PUJOL, R. (1997). Synaptic repair mechanisms responsible for functional recovery in various cochlear pathologies. Acta Otolaryngo/117: 214-8.

RASK-ANDERSEN, H., BOSTROM, M., GERDIN, B., KINNEFORS, A., NYBERG, G., ENGSTRAND, T., MILLER, J.M. and LINDHOLM, D. (2005). Regeneration of human auditory nerve. In vitro/in video demonstration of neural progenitor cells in adult human and guinea pig spiral ganglion. Hear Res 203: 180-91.

REH, T.A. and FISCHER, A.J. (2006). Retinal stem cells. Methods Enzymo/419: 52-73.

REYNOLDS, B.A. and WEISS, S. (1992). Generation of neurons and astrocytes from isolated cells of the adult mammalian central nervous system. Science 255: $1707-10$.

RIETZE, R.L., VALCANIS, H., BROOKER, G.F., THOMAS, T., VOSS, A.K. and BARTLETT, P.F. (2001). Purification of a pluripotent neural stem cell from the adult mouse brain. Nature 412: 736-9.

SAGE, C., HUANG, M., KARIMI, K., GUTIERREZ, G., VOLLRATH, M.A., ZHANG, D.S., GARCIA-ANOVEROS, J., HINDS, P.W., CORWIN, J.T., COREY, D.P. et al. (2005). Proliferation of functional hair cells in vivo in the absence of the retinoblastoma protein. Science 307: 1114-8.

SCARFONE, E., DEMEMES, D. and SANS, A. (1991). Synapsin I and Synaptophysin expression during ontogenesis of the mouse peripheral vestibular system. $J$ Neurosci11: 1173-81.

SCHWAMBORN, J.C. and PUSCHEL, A.W. (2004). The sequential activity of the GTPases Rap1B and Cdc42 determines neuronal polarity. NatNeurosci7: 9239.

SCHWARTING, G.A., RAITCHEVA, D., CRANDALL, J.E., BURKHARDT, C. and PUSCHEL, A.W. (2004). Semaphorin 3A-mediated axon guidance regulates convergence and targeting of P2 odorant receptor axons. Eur J Neurosci 19:
1800-10.

SEKIYA, T., KOJIMA, K., MATSUMOTO, M., KIM, T.S., TAMURA, T. and ITO, J. (2006). Cell transplantation to the auditory nerve and cochlear duct. Exp Neurol 198: 12-24.

SEKIYA, T., SHIMAMURA, N., YAGIHASHI, A. and SUZUKI, S. (2003). Effect of topically applied basic fibroblast growth factor on injured cochlear nerve. Neurosurgery 52: 900-7; discussion 907.

SHI, F., CORRALES, C.E. and EDGE, A.S.B. (2007). Sensory neurons produced by induction of human ES cells with BMP4: engraftment in the organ of Corti Association for Research in Otolarygology Abstract, Annual Meeting.

SHIRVAN, A., KIMRON, M., HOLDENGREBER, V., ZIV, I., BEN-SHAUL, Y., MELAMED, S., MELAMED, E., BARZILAI, A. and SOLOMON, A.S. (2002). Antisemaphorin $3 A$ antibodies rescue retinal ganglion cells from cell death following optic nerve axotomy. J Biol Chem 277: 49799-807.

STANKOVIC, K., RIO, C., XIA, A., SUGAWARA, M., ADAMS, J.C., LIBERMAN, M.C. and CORFAS, G. (2004). Survival of adult spiral ganglion neurons requires erbB receptor signaling in the inner ear. J Neurosci24: 8651-61.

STARR, A., PICTON, T.W., SININGER, Y., HOOD, L.J. and BERLIN, C.I. (1996). Auditory neuropathy. Brain 119 (Pt 3): 741-53.

SUGAWARA, M., CORFAS, G. and LIBERMAN, M.C. (2005). Influence of supporting cells on neuronal degeneration after hair cell loss. JAssoc Res Otolaryngol 6: 136-47.

TAMURA, T., NAKAGAWA, T., IGUCHI, F., TATEYA, I., ENDO, T., KIM, T.S., DONG, Y., KITA, T., KOJIMA, K., NAITO, Y. et al. (2004). Transplantation of neural stem cells into the modiolus of mouse cochleae injured by cisplatin. Acta Otolaryngol Supp65-8.

TATEYA, I., NAKAGAWA, T., IGUCHI, F., KIM, T.S., ENDO, T., YAMADA, S., KAGEYAMA, R., NAITO, Y. and ITO, J. (2003). Fate of neural stem cells grafted into injured inner ears of mice. Neuroreport 14: 1677-81.

TAUPIN, P. and GAGE, F.H. (2002). Adult neurogenesis and neural stem cells of the central nervous system in mammals. J Neurosci Res 69: 745-9.

TEMPLE, S. (2001). The development of neural stem cells. Nature 414: 112-7.

TOMITA, Y., MATSUMURA, K., WAKAMATSU, Y., MATSUZAKI, Y., SHIBUYA, I., KAWAGUCHI, H., IEDA, M., KANAKUBO, S., SHIMAZAKI, T., OGAWA, S. et al. (2005). Cardiac neural crest cells contribute to the dormant multipotent stem cell in the mammalian heart. $J$ Cel/ Bio/170: 1135-46.

VARGA, R., KELLEY, P.M., KEATS, B.J., STARR, A., LEAL, S.M., COHN, E. and KIMBERLING, W.J. (2003). Non-syndromic recessive auditory neuropathy is the result of mutations in the otoferlin (OTOF) gene. J Med Genet 40: 45-50.

WARCHOL, M.E., LAMBERT, P.R., GOLDSTEIN, B.J., FORGE, A. and CORWIN, J.T. (1993). Regenerative proliferation in inner ear sensory epithelia from adult guinea pigs and humans. Science 259: 1619-22.

WATTS, C., MCCONKEY, H., ANDERSON, L. and CALDWELL, M. (2005). Anatomical perspectives on adult neural stem cells. J Anat207: 197-208.

WHITE, P.M., DOETZLHOFER, A., LEE, Y.S., GROVES, A.K. and SEGIL, N. (2006). Mammalian cochlear supporting cells can divide and trans-differentiate into hair cells. Nature 441: 984-7.

WISE, A.K., RICHARDSON, R., HARDMAN, J., CLARK, G. and O'LEARY, S. (2005). Resprouting and survival of guinea pig cochlear neurons in response to the administration of the neurotrophins brain-derived neurotrophic factor and neurotrophin-3. J Comp Neuro/487: 147-65.

YERUKHIMOVICH, M.V., BAI, L., CHEN, D.H., MILLER, R.H. and ALAGRAMAM, K.N. (2007). Identification and characterization of mouse cochlear stem cells. Dev Neurosci29: 251-60.

ZHAI, S., SHI, L., WANG, B.E., ZHENG, G., SONG, W., HU, Y. and GAO, W.Q. (2005). Isolation and culture of hair cell progenitors from postnatal rat cochleae.£J Neurobio/65: 282-93.

Published Online: 12th September 2007 


\section{Related, previously published Int. J. Dev. Biol. articles \\ See our Special Issue Ear Development edited by Fernando Giraldez and Bernd Fritzsch at: http://www.ijdb.ehu.es/web/contents.php?vol=51\&issue=6-7}

Neural differentiation from human embryonic stem cells in a defined adherent culture condition Hossein Baharvand, Narges-Zare Mehrjardi, Maryam Hatami, Sahar Kiani, Mahendra Rao and MahdiMontazer Haghighi

Int. J. Dev. Biol. (2007) 51: 371-378

Pax7 identifies neural crest, chromatophore lineages and pigment stem cells during zebrafish development

Ana M Lacosta, Jesús Canudas, Cristina González, Pedro Muniesa, Manuel Sarasa and Luis Domínguez Int. J. Dev. Biol. (2007) 51: 327-331

Axon guidance in the inner ear Donna M. Fekete and Andrea M. Campero

Int. J. Dev. Biol. (2007) 51 doi: 10.1387/ijdb.072341df

Analysis of Netrin 1 receptors during inner ear development

Tanja Matilainen, Maarja Haugas, Jordan A. Kreidberg and Marjo Salminen

Int. J. Dev. Biol. (2007) 51: 409-414

Cell proliferation during the early compartmentalization of the Xenopus laevis inner ear Quincy A. Quick and Elba E. Serrano

Int. J. Dev. Biol. (2007) 51: 201-210

Enhanced development of porcine embryos cloned from bone marrow mesenchymal stem cells Hai-Feng Jin, B. Mohana Kumar, Jung-Gon Kim, Hye-Jin Song, Yeon-Ji Jeong, Seong-Keun Cho, Sivasankaran Balasubramanian, Sang-Yong Choe and Gyu-Jin Rho

Int. J. Dev. Biol. (2007) 51: 85-90

Differentiation of human embryonic stem cells into hepatocytes in 2D and 3D culture systems in vitro Hossein Baharvand, Seyed M. Hashemi, Saeid Kazemi Ashtiani and Ali Farrokhi

Int. J. Dev. Biol. (2006) 50: 645-652

Common culture conditions for maintenance and cardiomyocyte differentiation of the human embryonic stem cell lines, BG01 and HUES-7

Chris Denning, Cinzia Allegrucci, Helen Priddle, Maria D. Barbadillo-Muñoz, David Anderson, Tim Self, Nigel M. Smith, C. Tony Parkin and Lorraine E. Young

Int. J. Dev. Biol. (2006) 50: 27-37

Expression of regulatory genes for pancreas development during murine embryonic stem cell differentiation

Josué K. Mfopou, Erik Willems, Luc Leyns and Luc Bouwens

Int. J. Dev. Biol. (2005) 49: 915-922 